\title{
OPEN Recent discoveries of new Elephantomyia (Diptera, Limoniidae) fossils in Baltic amber
}

\author{
Iwona Kania-Kłosok ${ }^{1 \bowtie}$ \& Wiesław Krzemiński
}

New data on the genus Elephantomyia (Diptera: Limoniidae) from Baltic amber are presented. A new subgenus Hoffeinsonia subgen. nov. is established with one new species: Elephantomyia (Hoffeinsonia) prima sp. nov. The new subgenus is characterized by a wing at most $2.5 \times$ as long as it is wide without a darker pattern along the veins $S c$ and $R_{1}$, elongate $S c$, straight vein $R_{1}$, sharp half of vein $R_{2+3+4}$ sharply arched to the upper edge of the wing, short, wide, trapezoidal d-cell and oval pterostigma. The fossil subgenus Hoffeinsonia subgen. nov. shares features with the extant subgenera Elephantomyodes and Elephantomyia. One other extinct species of Elephantomyia was discovered and described herein as $E$. (s. str.) christelae sp. nov. Such features as a very elongate vein $R_{2+3+4}, 2.5 \times$ as long as the $R s$ easily allowing this new species to be distinguished from the other fossil representatives of the genus Elephantomyia. The taxonomic decision on Elephantomyia grata as a species placed in nominative subgenus is provided. A list and key of fossil species of Elephantomyia are given. The morphological pattern of the genus is discussed in relation to the adaptation to a specific food spectrum, coevolution with Angiospermae of the representative genus Helius known since Cretaceous and closely related to this genus representatives of the much younger genus Elephantomyia.

The genus Elephantomyia Osten Sacken ${ }^{1}$, comprises over 140 extant species, which occur mainly in Neotropical and Afrotropical regions. In the Neotropics, the genus Elephantomyia is represented by 38 species, which belongs to three subgenera: the typical subgenus Elephantomyia, subgenus Elephantomyina Alexander ${ }^{2}$ (one species) and the subgenus Xenoelephantomyia Alexander ${ }^{3}$ (one species). In the Afrotropics, the genus Elephantomyia is represented by over 30 species, which are classified to only one subgenus Elephantomyia. The subgenus Elephantomyodes Alexander ${ }^{4}$ was recorded from Holarctic (only two species), from China /Hainan, Taiwan/, India / Tamil Nadu, Assam/, Malaysia /Borneo/, Indonesia/Java, Sumatra, Flores, Sulawesi/, Philippines, Thailand) (18 species) and Australian/Oceanian region (13 species $)^{5}$.

From fossil record seven species of Elephantomyia are known, six of them are known to have come from Eocene Baltic amber and belong to nominative subgenus Elephantomyia ${ }^{6-8}$. We only know of one species of Elephantomyia from Miocene to this day unclassified to any subgenus-Elephantomyia grata Podenas \& Poinar ${ }^{9}$ (Table 1; Fig. 1). None of the other three subgenera of Elephantomyia: Elephantomyina, Elephantomyodes, Xenoelephantomyia have so far been found in the fossil record.

Baltic amber forms the largest amber deposit in the world and is a relevant source for fossil insects. Diptera are largely dominant and diverse among animal inclusions in this kind of resin what may be related to the fact that the deposits of the Eocene Baltic amber were formed over a relatively long time and under various environmental conditions ${ }^{10}$.

The new materials under investigation made it possible to discover a representative of a new subgenus of Elephantomyia in the fossil material. This new, peculiar discovery from Baltic amber described herein, provides evidence of the existence of craneflies belonging to a new subgenus in the Eocene and this is the first case to confirm the existence of a subgenus other than nominative the Elephantomyia in the past.

\author{
Results \\ Systematic palaeontology. Order Diptera Linnaeus ${ }^{11}$. \\ Infraorder Tipulomorpha Rohdendorf ${ }^{12}$. \\ Family Limoniidae Speiser ${ }^{13}$. \\ Subfamily Limoniinae Speiser ${ }^{13}$.
}

${ }^{1}$ Department of Biology, Institute of Biology and Biotechnology, University of Rzeszów, Rzeszów, Poland. ${ }^{2}$ Institute of Systematics and Evolution of Animals, Polish Academy of Sciences, Krakow, Poland. $\square$ email: ikania@ univ.rzeszow.pl 


\begin{tabular}{|c|c|c|}
\hline Species & Age & Locality \\
\hline Elephantomyia (s. str.) grata Podenas \& Poinar ${ }^{9}$ & Miocene & Dominican amber \\
\hline Elephantomyia (s. str.) baltica Alexander ${ }^{6}$ & Eocene & Baltic amber \\
\hline Elephantomyia (s. str.) bozenae Kania ${ }^{8}$ & Eocene & Baltic amber \\
\hline Elephantomyia (s. str.) brevipalpa Loew $^{7}$ & Eocene & Baltic amber \\
\hline Elephantomyia (s. str.) irinae $\mathrm{Kania}^{8}$ & Eocene & Baltic amber \\
\hline Elephantomyia (s. str.) longirostris Loew & Eocene & Baltic amber \\
\hline Elephantomyia (s. str.) pulchella Loew ${ }^{7}$ & Eocene & Baltic amber \\
\hline
\end{tabular}

Table 1. List of fossil species belonging to the genus Elephantomyia described before the present study, with age and localities.

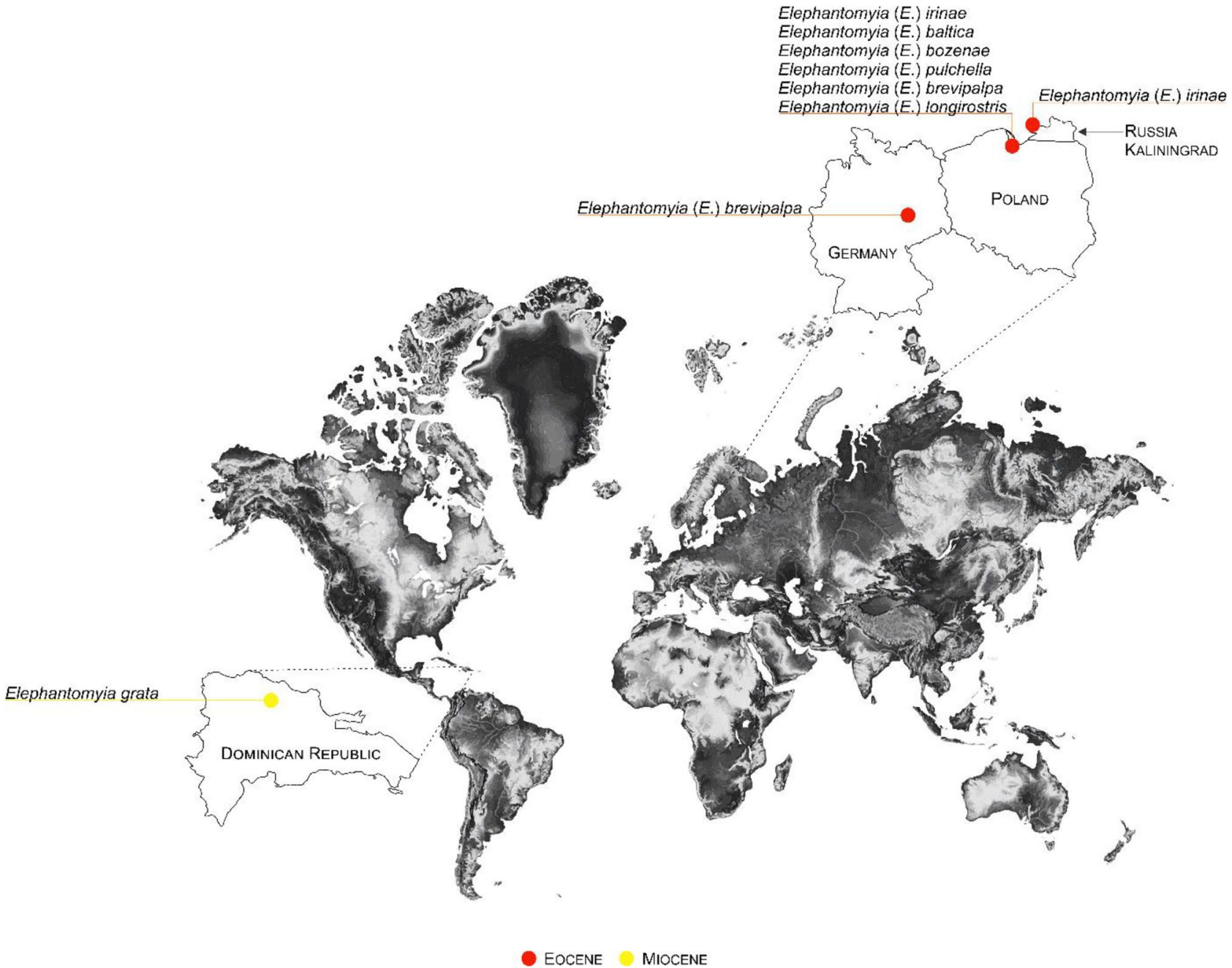

Figure 1. Map with enlarged view of the distribution of know localities of the representatives of the genus Elephantomyia. Map was built using the map Maps-For-Free (https:// maps- for- free. com) and modified with the software programs Corel Draw and Corel Photopaint X7.

Genus Elephantomyia Osten Sacken ${ }^{1}$.

Type species: Limnobiorhynchus canadensis Westwood ${ }^{14}: 684$, sensu Osten Sacken ${ }^{1}: 221$; by original designation (= westwoodi Osten Sacken ${ }^{15}: 109$, misidentification).

Elephantomyia Osten Sacken ${ }^{1}$ subg. Elephantomyia Alexander, 1938 emend.

Emended diagnosis Wing at most $2.5 \times$ as long as wide without darker pattern along vein $\mathrm{Sc}$ and $\mathrm{R}_{1}$; pterostigma oval; tip of Sc before or at Mb bifurcation level, opposite crossvein $\mathrm{m}$-cu; vein $\mathrm{R}_{1}$ slightly curved at the tip, vein $R_{2+3+4}$ slightly arched to the upper edge of wing, the distance between veins $R_{2+3+4}$ and $R_{1}$ and between veins $\mathrm{R}_{2+3+4}$ and $\mathrm{R}_{5}$ comparable; $\mathrm{d}$-cell almost rectangular; two anal veins well developed; gonostyles elongate, 


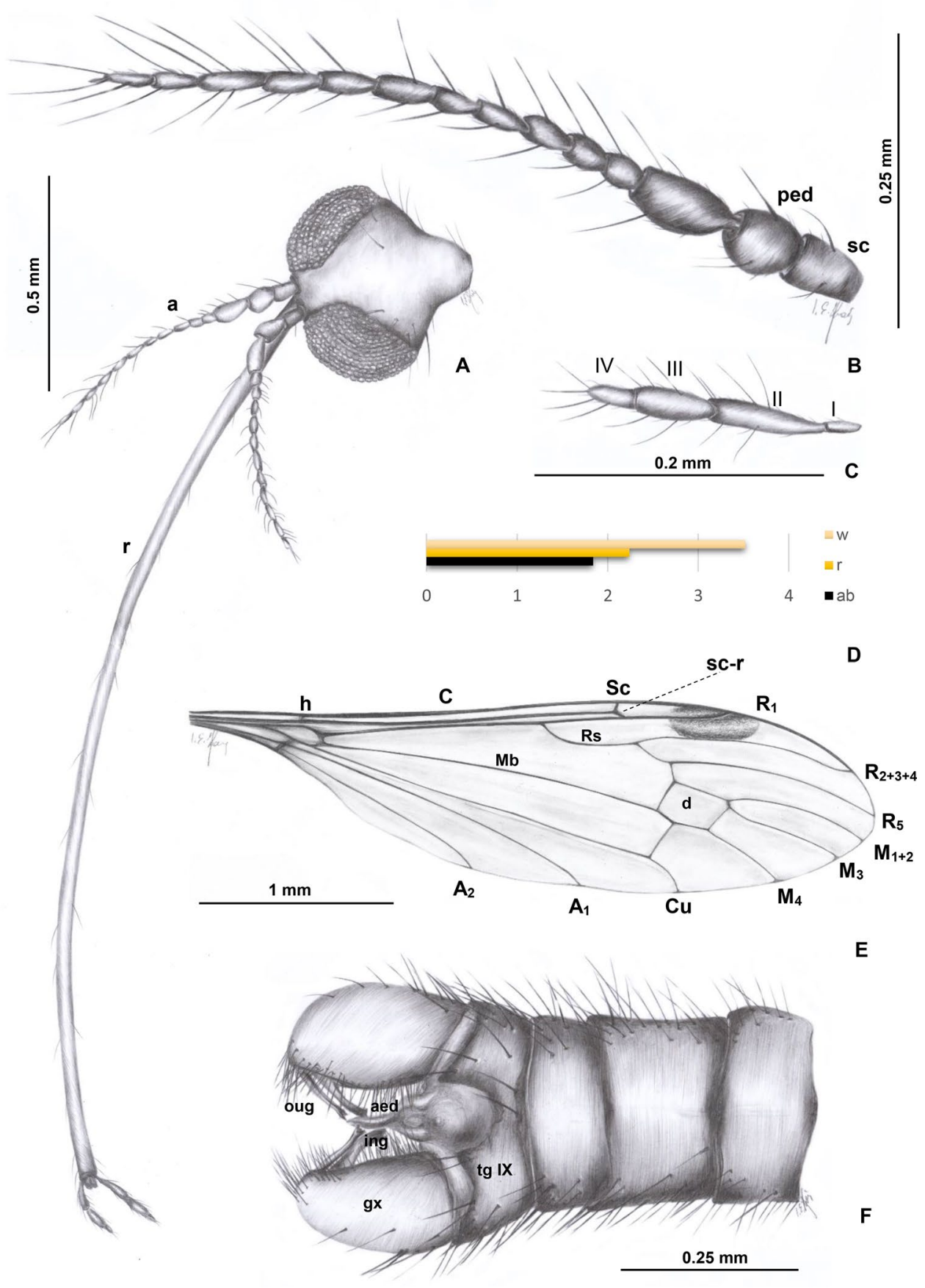

Figure 2. Elephantomyia (s. str.) christelae sp. nov. No. CCHH 874-2 (male), coll. Ch. \& H. W. Hoffeins, holotype, drawings: (A) head (ventral view); (B) antenna; (C) palpus; (D) the diagram illustrating the relationship between the length of wing (w), rostrum (r) and abdomen (ab); (E) wing; (F) hypopygium (dorsal view). Abbreviation: a-antenna; r-rostrum; ped-pedicel; scp-scape; I-IV-palpomeres I-IV; gxgonocoxite.

approximately $1 / 3$ the length of gonocoxite or longer, gonocoxites elongate but rather wide, approximately twice their width or shorter.

Elephantomyia (Elephantomyia) grata Podenas \& Poinar'.

Elephantomyia grata: Podenas \& Poinar': 867.

Remark The species Elephantomyia grata Podenas \& Poinar ${ }^{9}$ described from Dominican amber has not been classified into a subgenus so far. Based on species characteristics consistent with the diagnosis of the subgenus, we decided to classify E. grata under the subgenus Elephantomyia. E. grata subgeneric placement is based on the original description without examination of the type specimen.

Elephantomyia (Elephantomyia) christelae sp. nov. (Figs. 2, 3 and 4). 

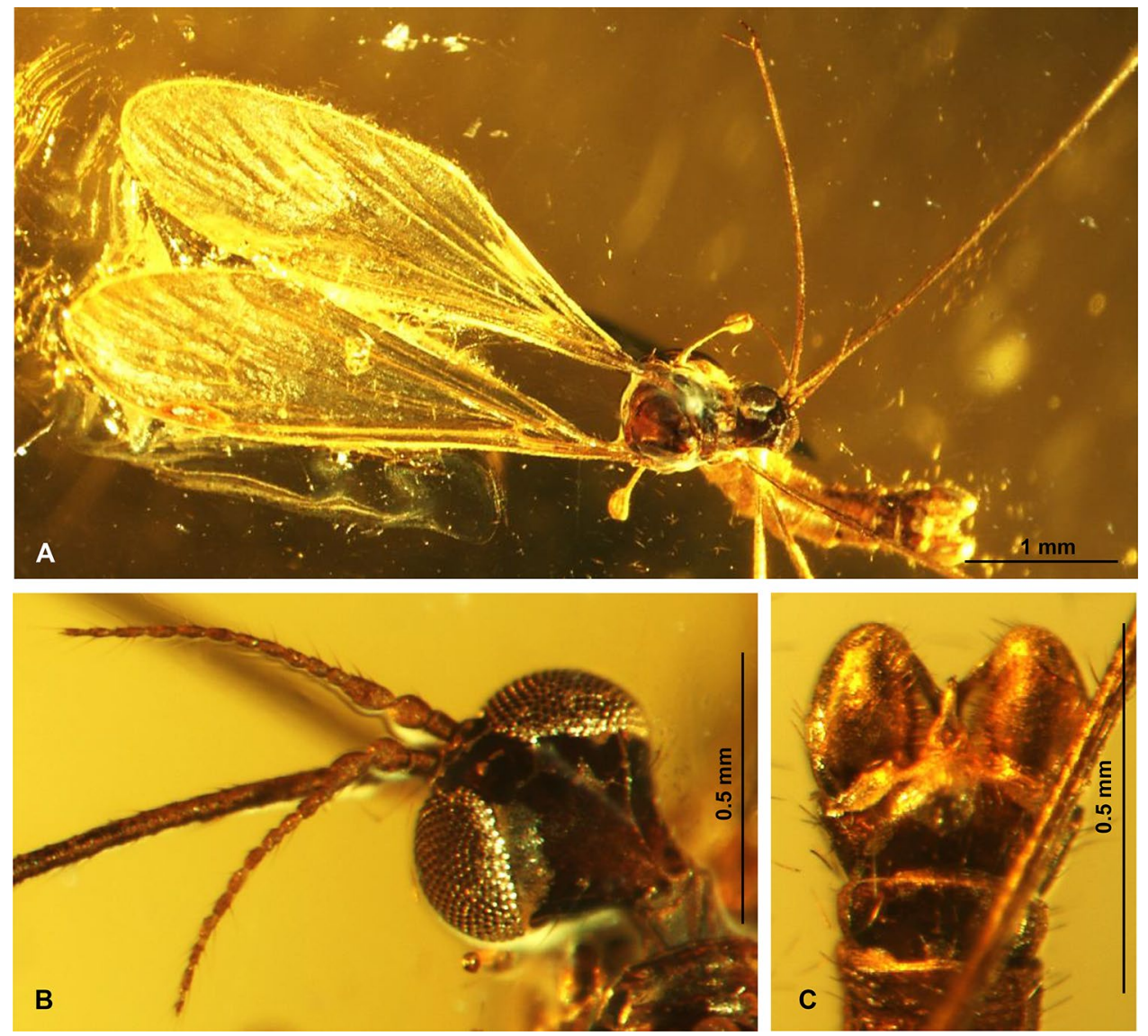

Figure 3. Elephantomyia (s. str.) christelae sp. nov. No. CCHH 874-2 (male), coll. Ch. \& H. W. Hoffeins, holotype, photographs: (A) the body (dorso-ventral view); (B) enlarged view of antenna; (C) hypopygium.

Diagnosis Antennae 14-segmented; rostrum shorter than wing, only slightly longer than 1/2 of wing, longer than abdomen; palpus longer than glossal lobes; $\mathrm{R}_{2+3+4}$ very elongate, $2.5 \times$ as long as $\mathrm{Rs}$; $\mathrm{d}$-cell short and wide, $1.5 \times$ as long as wide; $\mathrm{m}$-cu just before half the length of $\mathrm{d}$-cell; $\mathrm{M}_{3} 2 \times$ longer than $\mathrm{d}$-cell; vein $\mathrm{m}$-m very short, almost completely reduced; vein Rs relatively short, length of vein Rs arranges only about twice the length of the basal deflection of $\mathrm{R}_{5}$; shorter than $\mathrm{R}_{2+3+4}$.

Etymology The new species is dedicated to Christel Hoffeins from Hamburg, Germany, the amber collection owner and expert of the Baltic amber inclusions.

Material examined Holotype No. CCHH 874-2 (male), coll. Ch. \& H. W. Hoffeins, the specimen housed in Senckenberg Deutsches Entomologisches Institut (SDEI) Müncheberg, Germany.

Horizon and locality The age of Baltic amber has been a matter of debate for many years ${ }^{9,16-23}$. But, the most current state of knowledge is that it is of Priabonian age ${ }^{17}$. This means it is between 38 and 34 million years old (based on pollen, spores and phytoplankton of the amber embedding layer, the Blue Earth). The age of Baltic amber has also been estimated to approximately 47-41 Ma, which is mainly based on a study by Ritzkowski ${ }^{24}$; however, the reliability of the methods used in his study have been questioned due to contaminations that can lead to older age estimations ${ }^{16,17}$. The age range of all Baltic amber bearing strata possibly cover 48 to 23 million years, and it is still debatable $\left.{ }^{18-23}\right)$.

Description. Body (Fig. 3A): brown with dark distal part of abdomen darker than rest of body, body $3.28 \mathrm{~mm}$ long (without rostrum).

Head (Figs. 2A, 3A, 4B): $0.45 \mathrm{~mm}$ wide, $0.34 \mathrm{~mm}$ high; rostrum elongate $2.24 \mathrm{~mm}$ long, shorter than wing, terminate just behind half of wing, rostrum longer than abdomen (1.84 mm long) (Figs. 2D, 3A, 4B); antenna (Figs. 2A, B, 3A, B, 4B) small, $0.64 \mathrm{~mm}$ long, flagellar segments crowded, scape cylindrical, widened, pedicel wide, first flagellomere elongate, second flagellomere only slightly shorter than rest of flagellomeres, flagellomeres 1-8 with two elongate setae on each flagellomere; flagellomeres 9-12 with four elongate setae.

Palpus (Figs. 2C, 4A, B): longer than glossal lobes, $0.19 \mathrm{~mm}$ long, 4-segmented, last palpomeres short, other palpomeres elongate, third palpomere shorter than second. The small microtrichia on all segments well visible.

Wing (Figs. 2E, 3A, 4C): $3.52 \mathrm{~mm}$ long, $0.88 \mathrm{~mm}$ wide; pterostigma present, darkened, oval, brown; vein Sc elongate, ending opposite 3/4 the length of Rs; sc-r short, one time the distance from the tip of Sc; vein Rs slightly arcuated, $R_{1}$ ending before half of the length of $R_{2+3+4} ; r-r\left(R_{2}\right)$ atrophy; d-cell $0.26 \mathrm{~mm}$ long, $M_{3} 0.61 \mathrm{~mm}$ long; $\mathrm{A}_{1}$ almost straight, $\mathrm{A}_{2}$ slightly curved at wing margin. 


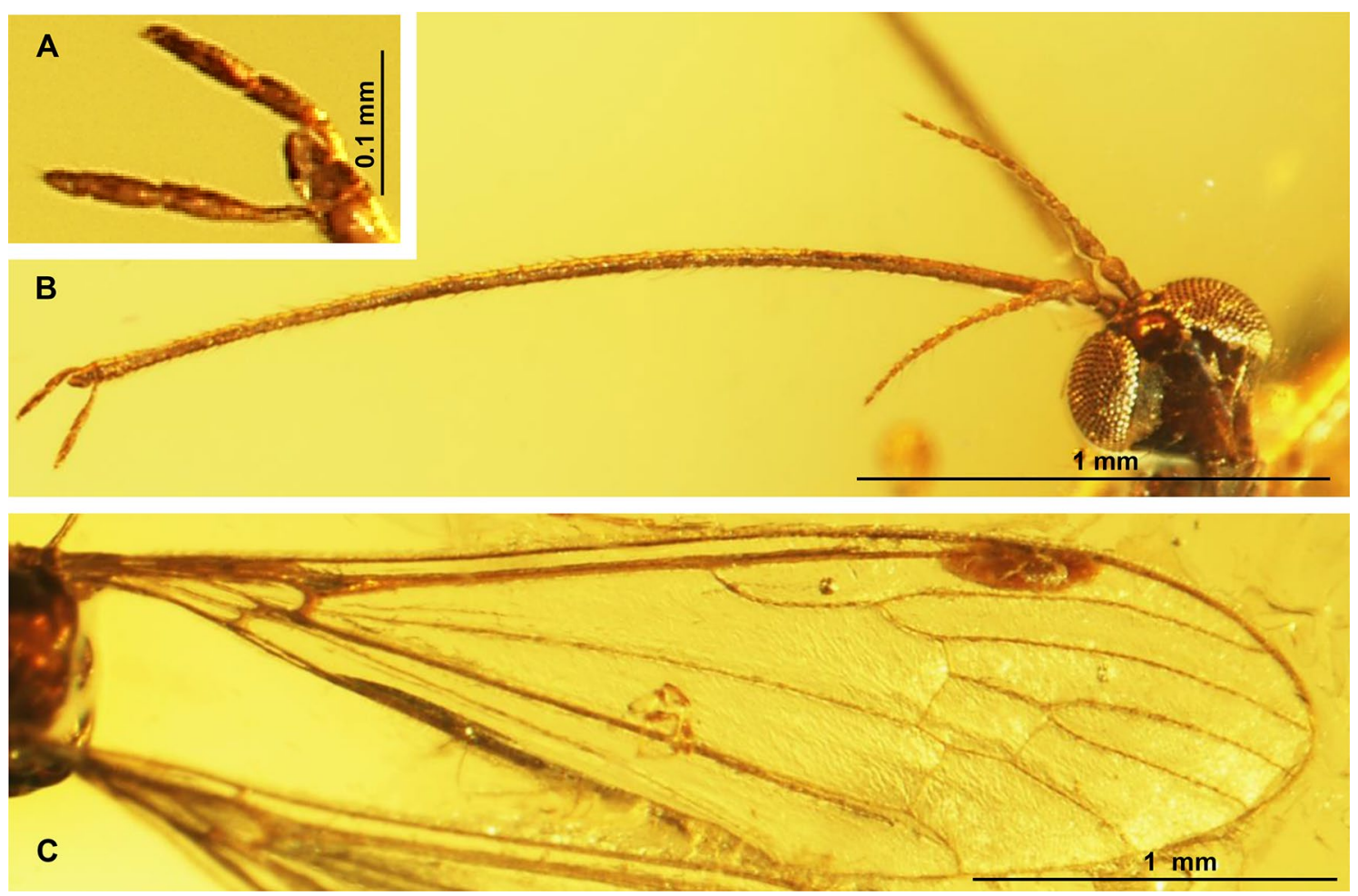

Figure 4. Elephantomyia (s. str.) christelae sp. nov. No. CCHH 874-2 (male), coll. Ch. \& H. W. Hoffeins, holotype, photographs: (A) palpi; (B) head; (C) wing.

Hypopygium (Figs. 2F, 3A, C): $0.46 \mathrm{~mm}$, gonocoxite approximately two times as long as wide with elongate and narrow, lobe-shaped interbase; male genitalia with lobe, outer gonostylus (branch II = clasper of gonostylus; ventral gonostylus) narrow, distinctly bifid at the end, the distal part slightly curved outside; inner gonostylus (branch I = lobe of gonostylus; dorsal gonostylus) slightly widened at base, directed inside of hypopygium.

Remarks A well preserved holotype specimen, but only partially preserved legs.

Comparison The species differ from all other known from fossil records due to the very short cross-vein $\mathrm{m}-\mathrm{m}$. Veins $\mathrm{M}_{1+2}$ and $\mathrm{M}_{3}$ in E. (E.) christelae sp. nov. is narrowly separated and the distance between veins $\mathrm{M}_{1+2} / \mathrm{M}_{3}$ is smaller than between veins $\mathrm{M}_{3} / \mathrm{M}_{4}$ while in other known fossil record species of Elephantomyia veins $\mathrm{M}_{1+2}$ and $M_{3}$ are widely separated and the distance between veins $M_{1+2} / M_{3}$ and veins $M_{3} / M_{4}$ is comparable, cross-vein $m-m$ is well developed. Moreover, this species is characterized by the occurrence of 15-segmented antenna while in E. (E.) baltica and E. (E.) brevipalpa antennae are 14-segmented. Palpus in E. (E.) christelae sp. nov. is elongate, longer than glossal lobes, while in $E$. (E.) brevipalpa palpus is very short, being less than half the length of the rostrum's glossal lobes. Vein Rs in E. (E.) brevipalpa is as long as, or longer than vein $\mathrm{R}_{2+3+4}$, in contrast to $E$. (E.) christelae sp. nov. where Rs is distinctly shorter than $\mathrm{R}_{2+3+4}$. E. (E.) christelae sp. nov. differs also from the other species of Elephantomyia in the ratio between wing, rostrum, and abdomen length. In E. (E.) christelae sp. nov. rostrum is slightly longer than the abdomen, being longer than half wing length, but shorter than wing.

Hoffeinsonia subgen. nov.

Type species: Elephantomyia (Hoffeinsonia) prima subgen. et sp. nov.

Diagnosis Wing at most $2.5 \times$ as long as wide without darker pattern along vein $\mathrm{Sc}$ and $\mathrm{R}_{1}$; pterostigma oval; vein Sc elongate, tip of Sc beyond Mb bifurcation level, opposite crossvein $\mathrm{m}$-cu; vein $\mathrm{R}_{1}$ straight, basal half of vein $R_{2+3+4}$ sharpy arched to the upper edge of wing, veins $R_{2+3+4}$ and $R_{1}$ runing closer together than veins $R_{2+3+4}$ and $\mathrm{R}_{5}$; d-cell short, wide, trapezoidal; two anal veins well developed; gonostyles small, about $1 / 3$ length of gonocoxite, gonocoxites elongate and rather narrow, longer than twice their width.

Etymology The new subgenus is dedicated to Christel Hoffeins from Hamburg, Germany, the amber collection owner and expert of the Baltic amber inclusions.

Description As for species.

Comparison What occurs in Elephantomyina is a strong supernumerary cross-vein connecting vein $\mathrm{R}_{2+3+4}$ shortly before tip of latter, cross-vein $\mathrm{r}$-m connecting with Rs a short distance before its fork ${ }^{2}$, while in other subgenera of the genus Elephantomyia (including Hoffeinsonia subgen. nov.) the supernumerary cross-vein does not occur and cross-vein r-m connecting with Rs beyond of Rs. Moreover, as mentioned by Osten Sacken ${ }^{25}$ : „anal field of wing reduced in area, with a single vein", while in three other known subgenera of Elephantomyia and Hoffeinsonia subgen. nov. two well developed annal veins are observed.

Only the hind leg with part of the tarsus of the specimen of Hoffeinsonia subgen. nov. is preserved, but is clearly visible that basal and middle part of femur and part of tibia are pale. This feature and others such as: vein $\mathrm{R}_{1}$ straight, basal half of vein $\mathrm{R}_{2+3+4}$ sharply arched to the upper edge of wing, veins $\mathrm{R}_{2+3+4}$ and $\mathrm{R}_{1}$ running closer together than veins $\mathrm{R}_{2+3+4}$ and $\mathrm{R}_{5}$, reduced palpi are similar to these which occur in subgenus Elephantomyodes. 


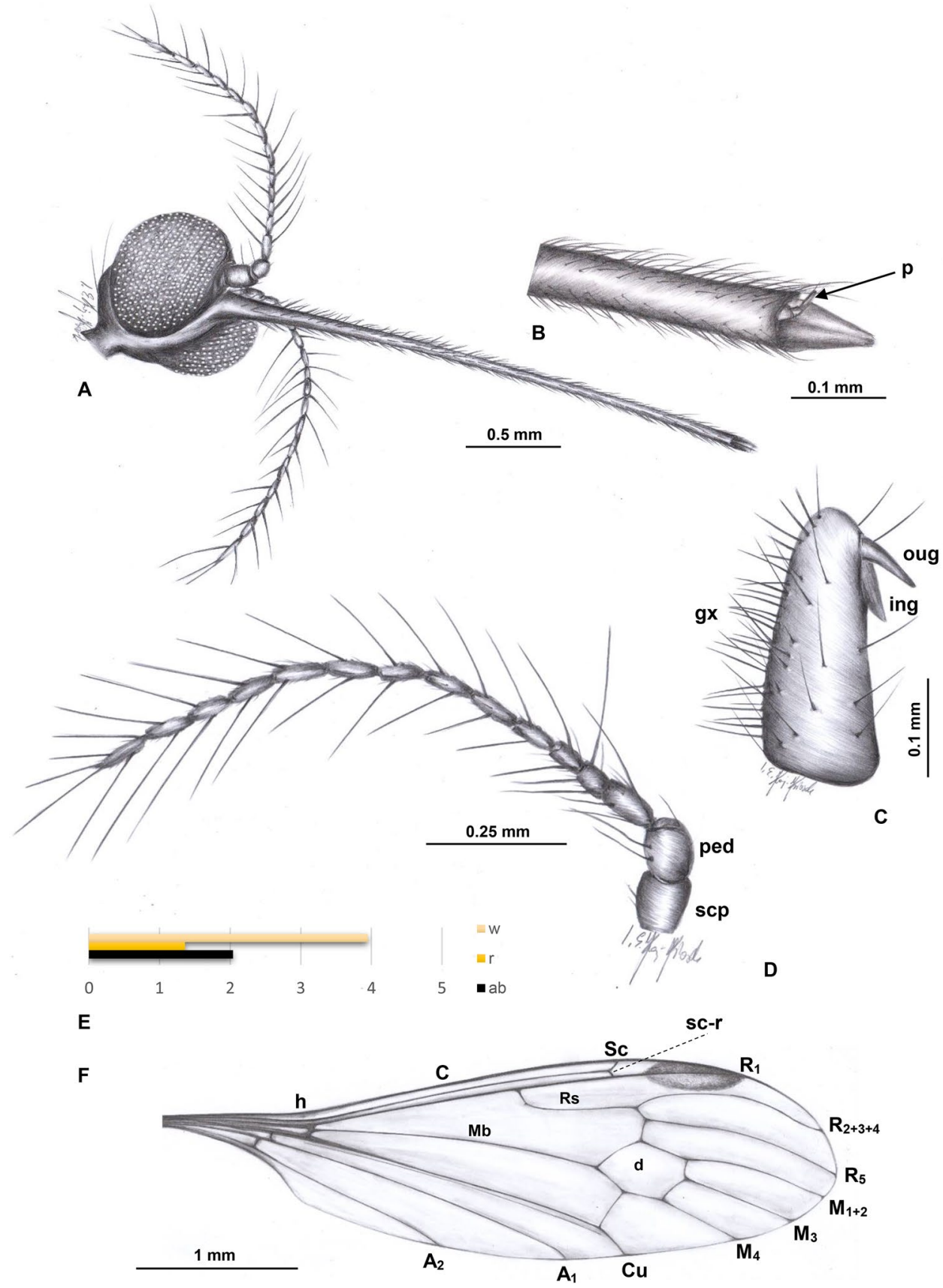

Figure 5. Elephantomyia (Hoffeinsonia) prima sp. nov. No. CCHH 874-1 (male), coll. Ch. \& H. W. Hoffeins, holotype, drawings: (A) head, latero-ventral view; (B) enlarged view of apical part of rostrum; (C) gonocoxite and gonostyles; (D) antenna; (E) the diagram illustrating the relationship between the length of wing $(\mathrm{w})$, rostrum (r) and abdomen (ab); (F) wing. Abbreviation: a-antenna; ped-pedicel; scp-scape; I-IVpalpomeres I-IV; gx—gonocoxite; oug-outer gonostylus; ing-inner gonostylus; $\mathrm{p}$ - palpus.

The afore mentioned features are well visible in recent representatives of the subgenus as Elephantomyia (Elephantomyodes) tianmushana Zhang, Li and Yang ${ }^{26}$, Elephantomyia (Elephantomyodes) sophiarum Ito $^{27}$, Elephantomyia (Elephantomyodes) angusticellula Alexander ${ }^{28}$ or Elephantomyia (Elephantomyodes) major major Alexander ${ }^{4}$. Pterostigma in Hoffeinsonia subgen. nov. is distinctly oval, like in Elephantomyia. The wing of Hoffeinsonia subgen. nov. is wider than the wing of Elephantomyodes and arrange at most $2.5 \times$ the length of its width, while the wing of Elephantomyodes 3.5x. Moreover, in Elephantomyodes along vein Sc and $\mathrm{R}_{1}$ occur darker pattern, in contrast to Hoffeinsonia subgen. nov.

Elephantomyia (Hoffeinsonia) prima subgen. et sp. nov. (Figs. 5, 6, and 7).

Diagnosis Antennae 15-segmented; rostrum shorter than wing, shorter than $1 / 2$ of wing, shorter than abdomen; palpus shorter than glossal lobes; $\mathrm{R}_{2+3+4} 1.5 \times$ as long as Rs; $\mathrm{d}$-cell approximately $1.5 \times$ as long as wide; $\mathrm{m}$-cu 

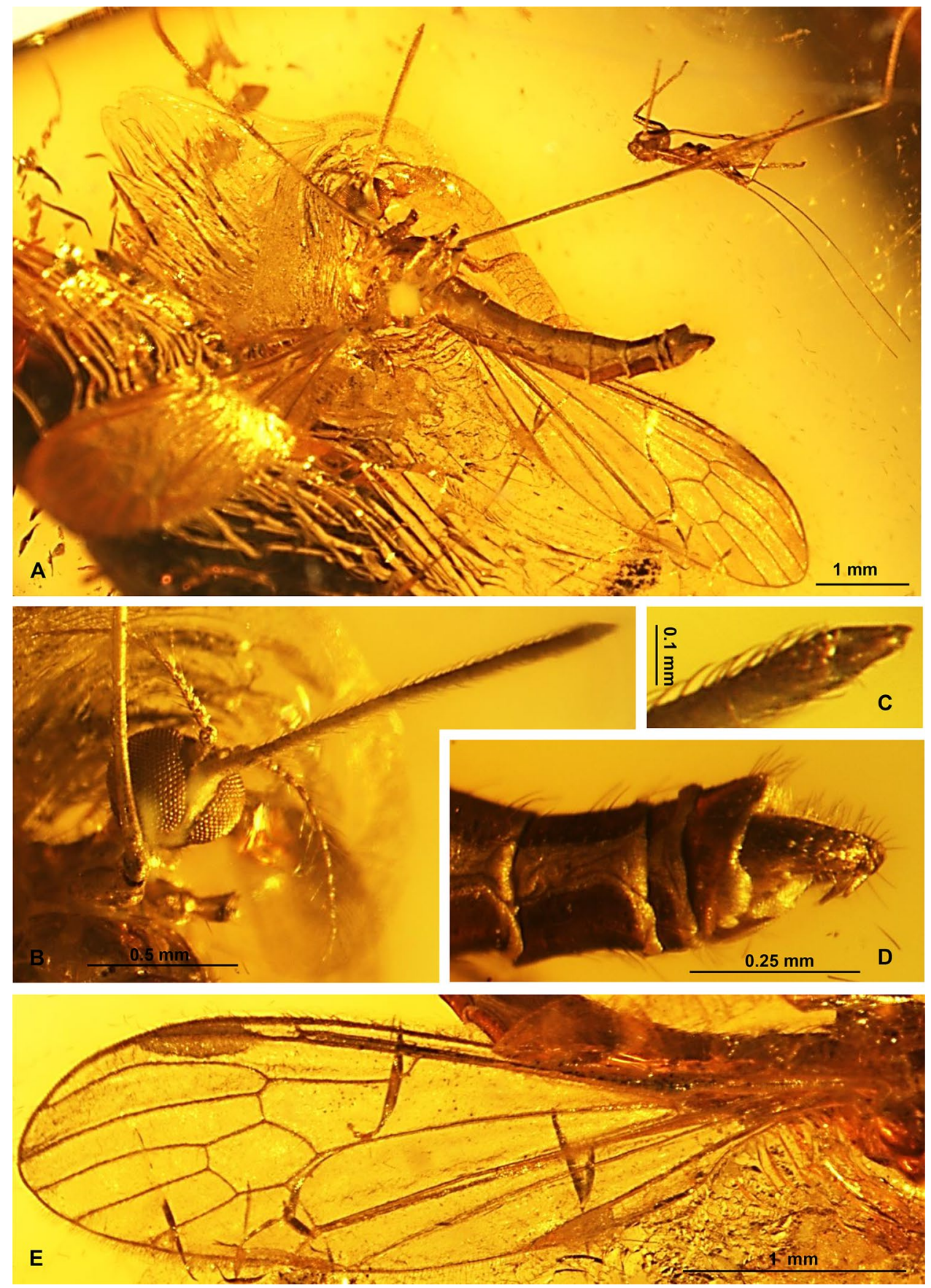

Figure 6. Elephantomyia (Hoffeinsonia) prima sp. nov. No. CCHH 874-1 (male), coll. Ch. \& H. W. Hoffeins, holotype, photographs: (A) body, latero-dorsal view; (B) head, latero-ventral view; (C) apical part of rostrum with palpi visible; (D) hypopygium, lateral view; (E) wing.

in half the length of d-cell; $\mathrm{M}_{3} 1.5 \times$ longer than d-cell; vein $\mathrm{m}$-m well developed; length of vein Rs arranges only about five the length of the basal deflection of $R_{5} ; R_{5}$ approximately as long as $R_{2+3+4}$.

Etymology. The specific epithet is derived from „prima” (Latin) $=$ the first.

Material examined. Holotype No. CCHH 874-1 (male), coll. Ch. \& H. W. Hoffeins, the specimen housed in Senckenberg Deutsches Entomologisches Institut (SDEI) Müncheberg, Germany.

Horizon and locality as for E. (s.str.) christelae sp. nov.

Description Body $3.61 \mathrm{~mm}$ long (Fig. 6A).

Head (Fig. 6B, C) width $0.42 \mathrm{~mm}, 0.38 \mathrm{~mm}$ high; rostrum $1.36 \mathrm{~mm}$ long, approximately as long as half the body length, shorter than half wing; length of antenna $0.72 \mathrm{~mm}$ (Fig. 5A); scape elongate, cylindrical, pedicel oval, wider than scape and other antennal segments, flagellomeres 1 and 2 only slightly elongate, longer than wide, flagellomeres 3-15 elongate, longer than twice of its width with very elongate setae, approximately twice 


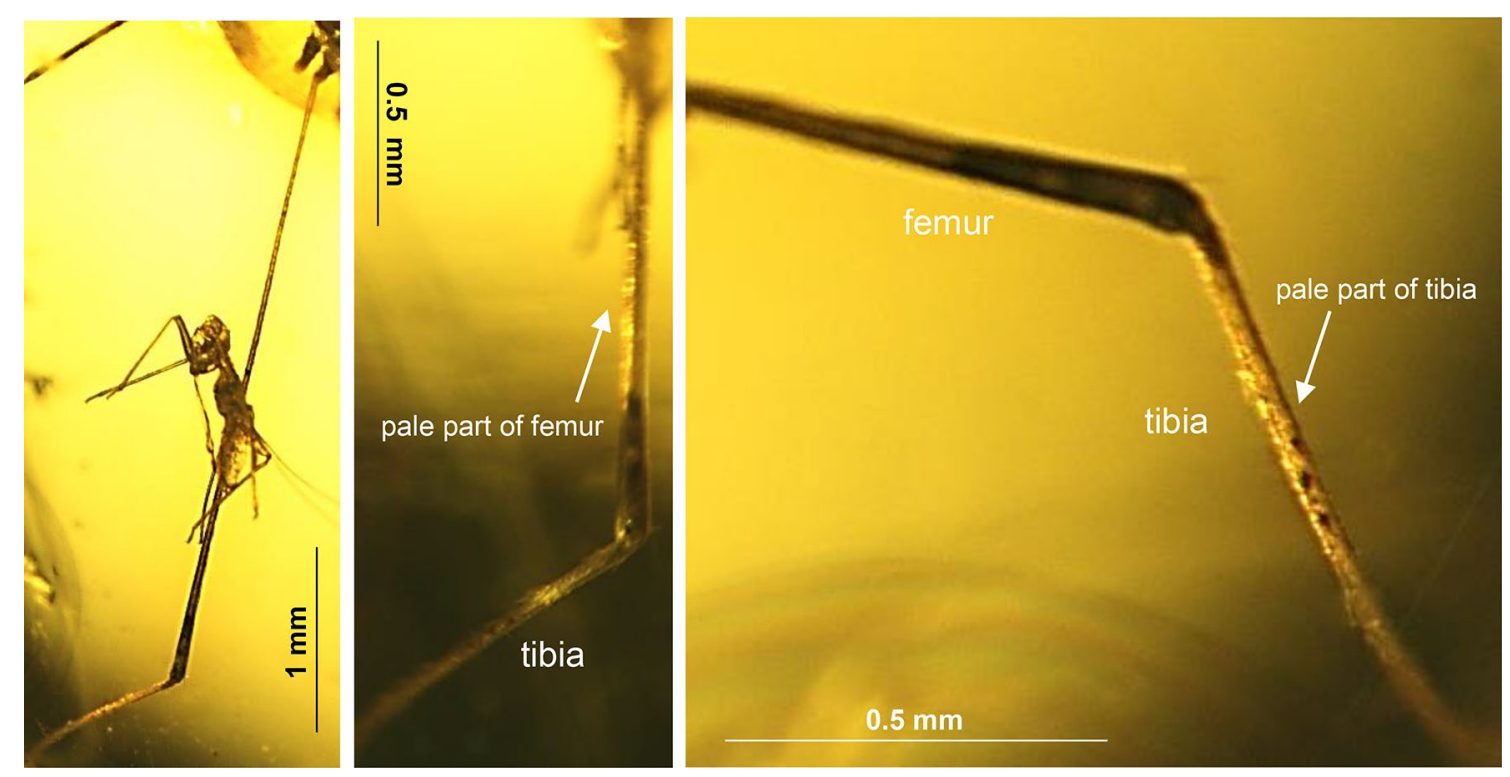

Figure 7. Elephantomyia (Hoffeinsonia) prima sp. nov. No. CCHH 874-1 (male), coll. Ch. \& H. W. Hoffeins, holotype, photographs: (A) femur and part of tibia of hind leg; (B) pale parts of femur and tibia of hind leg visible; (C) enlarged view of pale part of hind tibia.

as long as its width or longer; length of flagellomeres: $1 / 0.08 \mathrm{~mm} ; 2 / 0.06 \mathrm{~mm} ; 15 / 0.04 \mathrm{~mm}$; palpus very short, $0.13 \mathrm{~mm}$ long, shorter than glossal lobes.

Thorax (Fig. 6A): wing (Figs. 5B, 6A, E) longer than body, without colour pattern, $3.95 \mathrm{~mm}$ long, $1.10 \mathrm{~mm}$ wide; oval pterostigma brown, vein Sc elongate, tip of Sc beyond $\mathrm{Mb}$ bifurcation level, opposite crossvein $\mathrm{m}$-cu; cross-vein sc-r one of its length from the tip of Sc, fork of Rb beyond half the length of wing towards the apex of wing; fork of Rs beyond fork of $\mathrm{Mb}$ level and opposite approximately $1 / 3$ of $\mathrm{d}$-cell length measured from fork of Mb; Rs $0.70 \mathrm{~mm}$ long; $\mathrm{R}_{2+3+4}$ approximately $1.6 \times$ as long as Rs; cross-vein $\mathrm{m}$-cu in half the length of $\mathrm{d}$-cell; d-cell $0.42 \mathrm{~mm}$ long, wide, approximately $1.5 \times$ as long as wide; length of $\mathrm{M}_{3} 0.64 \mathrm{~mm}$; tip of $\mathrm{A}_{1}$ beyond fork of $\mathrm{Mb}$ toward the apex of wing; macrotrichia on radial and medial veins occur, vein $\mathrm{M}_{3}$ with macrotrichia arranged close to each other at equal intervals; hind legs with pale parts of femur and tibia (Fig. 7A-C).

Abdomen (Fig. 6A) $2.04 \mathrm{~mm}$ long; hypopygium $0.37 \mathrm{~mm}$ long with lobe-short, small, comparable length gonostyles, outer gonostylus (branch II = clasper of gonostylus; dorsal gonostylus) narrow, tappered at the end, strongly sclerotized, inner gonostylus (branch II = lobe of gonostylus; dorsal gonostylus) widened at the base and in its middle, narrowed at the end (Fig. 6D), less sclerotized than the outer gonostylus.

Remarks Well preserved holotype specimen, but only partially preserved legs.

Key to fossil species of the genus Elephantomyia.

1. Rostrum longer than half wing length (Fig. 10A-H); tip of Sc before or at fork of $\mathrm{Mb}$, before crossvein $\mathrm{m}$-cu measured from the base of the wing; vein $R_{1}$ at least slightly curved at the tip; vein $R_{2+3+4}$ with a slight curve to the upper edge of wing, the distance between veins $R_{2+3+4} / R_{1}$ and veins $R_{2+3+4} / R_{5}$ comparable (Fig. 9A); gonostyles elongate, about $1 / 2$ of the length of gonocoxite (Fig. $2 \mathrm{~F}$ ); 2.

Rostrum measures approximately $1 / 3$ of wing length (Fig. 10I); tip of Sc far beyond fork of Mb measured from the base of the wing, opposite crossvein $\mathrm{m}$-cu ; vein $\mathrm{R}_{1}$ straight; basal half of vein $\mathrm{R}_{2+3+4}$ sharply arched to the upper edge of wing; veins $R_{2+3+4}$ and $R_{1}$ closer together than veins $R_{2+3+4}$ and $R_{5}$ (Fig. 9D); gonostyles small, about $1 / 3$ length of gonocoxite (Fig. 5C);

E. (Hoffeinsonia) prima subgen et sp. nov

2. Veins $M 1+2$ and $M 3$ widely separated; the distance between veins $M 1+2 / M 3$ and veins M3/M4 comparable; cross-vein $\mathrm{m}$-m well developed (Fig. 8A-H) ................. 3.

- Veins $M_{1+2}$ and $M_{3}$ narrowly separated; the distance between veins $M_{1+2} / M_{3}$ smaller

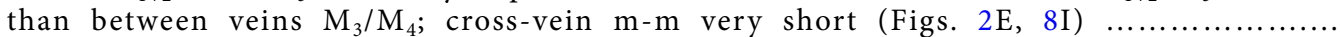
E. (s. str.) christelae sp. nov.

3. Wings longer than rostrum (Fig. 10A, C-I); relatively short vein Rs, the length of vein Rs at least three times of the basal deflection of $\mathrm{R}_{5}$ 4.

Wings as long as rostrum (Fig. 10B); the length Rs only slightly longer than twice the length of the basal deflection of $\mathrm{R}_{5}$ (Fig. 8C)

E. (s. str.) baltica Alexander ${ }^{6}$

4. Palpus longer than the glossal lobes; antennae 15-segmented; Rs distinctly shorter than $\mathrm{R} 2+3+4$ 


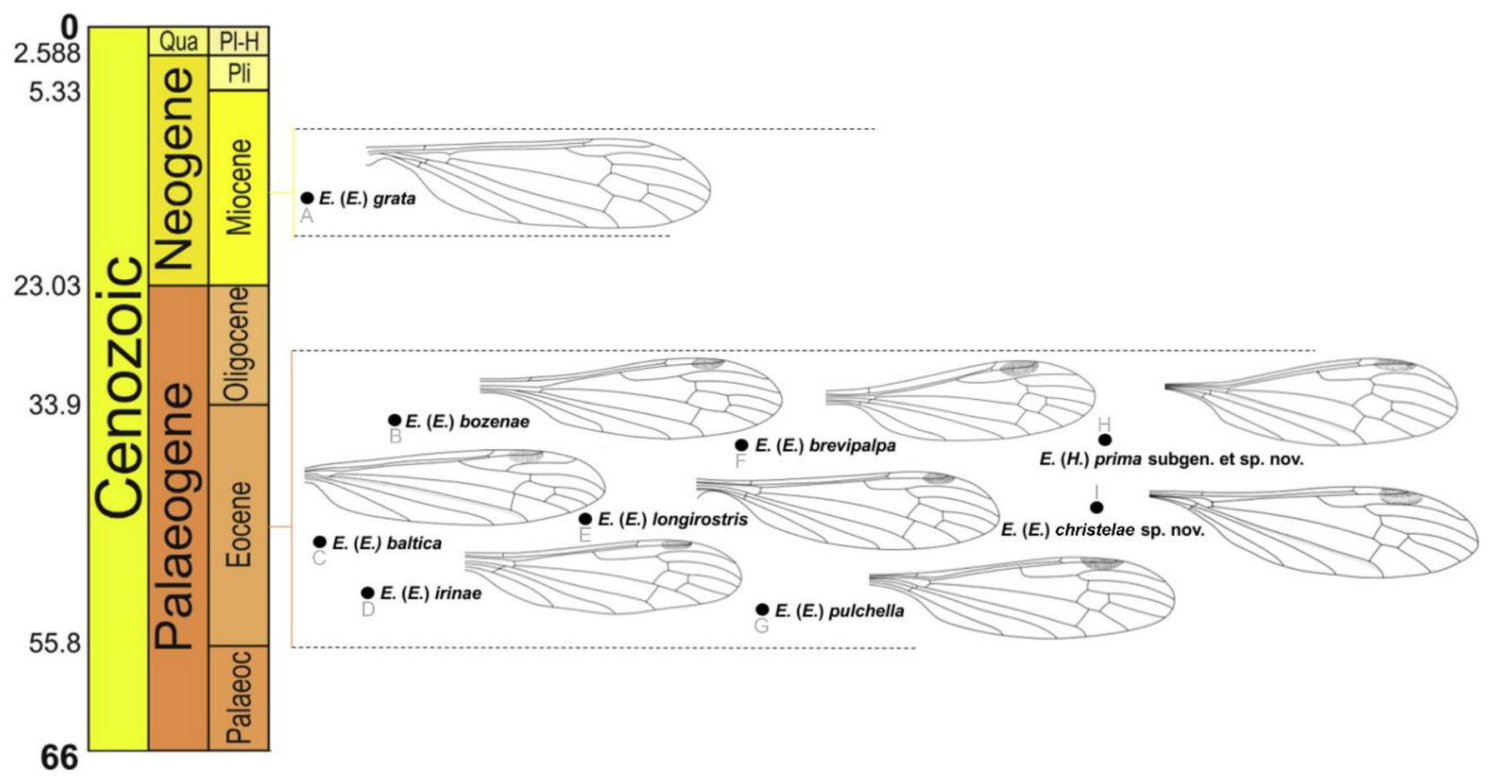

Figure 8. Chronostratigraphic distribution of Elephantomyia, fossil species, wings redrawn after Podenas and Poinar $^{9} ;$ Kania $^{8}$. Stratigraphic chart according to International Stratigraphic Chart, International Commission of Stratigraphy (v. 2021/05) https://stratigraphy.org/ chart (accessed on 16 September 2021).
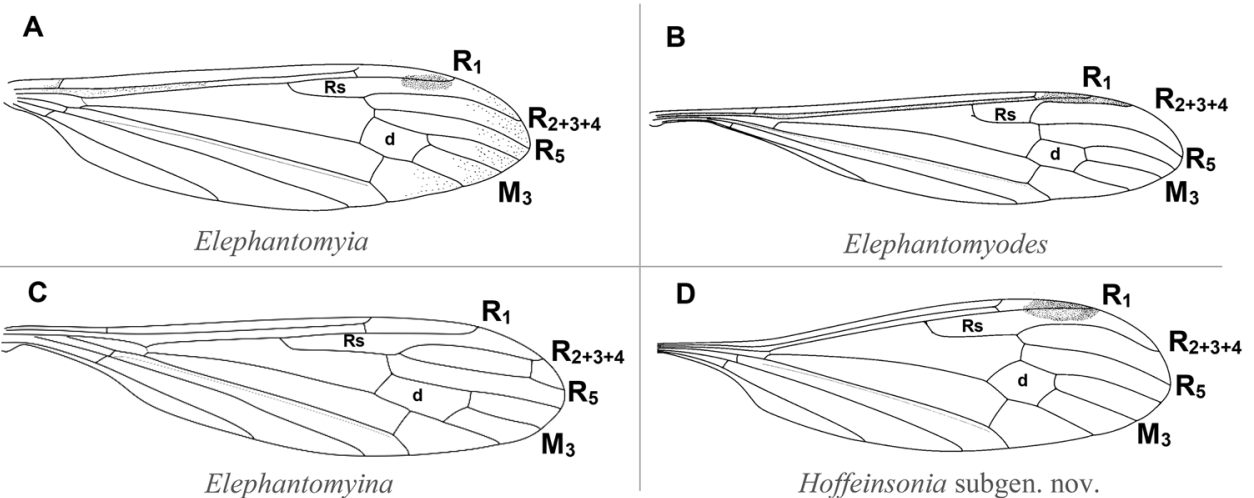

Figure 9. Wing venation of species belonging to different subgenera of genus Elephantomyia: (A) Elephantomyia (s. str.) edwardsi Lackschewitz ${ }^{35}$ (redrawn $\left.^{36}\right)$; (B) Elephantomyia (Elephantomyodes) major major Alexander ${ }^{4}\left(\right.$ redrawn $\left.^{17}\right)$; (C) Elephantomyia (Elephantomyina) supernumeraria Alexander ${ }^{37}\left(\right.$ (edrawn $\left.^{2}\right) ;($ D) Elephantomyia (Hoffeinsonia) prima subgen. and sp. nov.

- Palpus shorter than one half of the glossal lobes of the rostrum; antennae 14-segmented; Rs as long as $\mathrm{R}_{2+3+4}$ or slightly longer (Fig. 8F)

E. (s. str.) brevipalpa Loew ${ }^{7}$.

5. D-cell distinctly elongate, narrow, approximately twice times as long as wide; vein M3 as long as d-cell

D-cell wide, approximetely1.5 times as long as wide; vein M3 1.5 times longer than $\mathrm{d}$-cell

......................................................... 7.

6. Fork of $\mathrm{Rb}$ far beyond half the length of wing, in $3 / 5$ the length of wing measured from the base of wing; Rs short, approximately as long as d-cell; gonocoxite at least three times as long as wide (Fig. 8A)

(s. str.) grata Podenas \& Poinar ${ }^{9}$

- Fork of $\mathrm{Rb}$ before half the length of wing or just beyond, measured from the base of wing; Rs at least $1.5 \times$ as long as d-cell; gonocoxite at most twice as long as wide (Fig. 8A) ..................................................... (s. str.) bozenae Kania ${ }^{8}$.

7. Rostrum not very elongate, shorter than abdomen, distinctly shorter than wing, only slightly longer than $1 / 2$ of wing length (Fig. 10E)

........................................................ (s. str.) irinae Kania ${ }^{8}$


A. E. (E.) grata

E. (E.) baltica

E. (E.) bozenae

E. (E.) brevipalpa

E. E. (E.) christelae sp. nov.

E. (E.) irinae

E. (E.) longirostris

E. (E.) pulchella

E. (H.) prima subgen. et sp. nov.
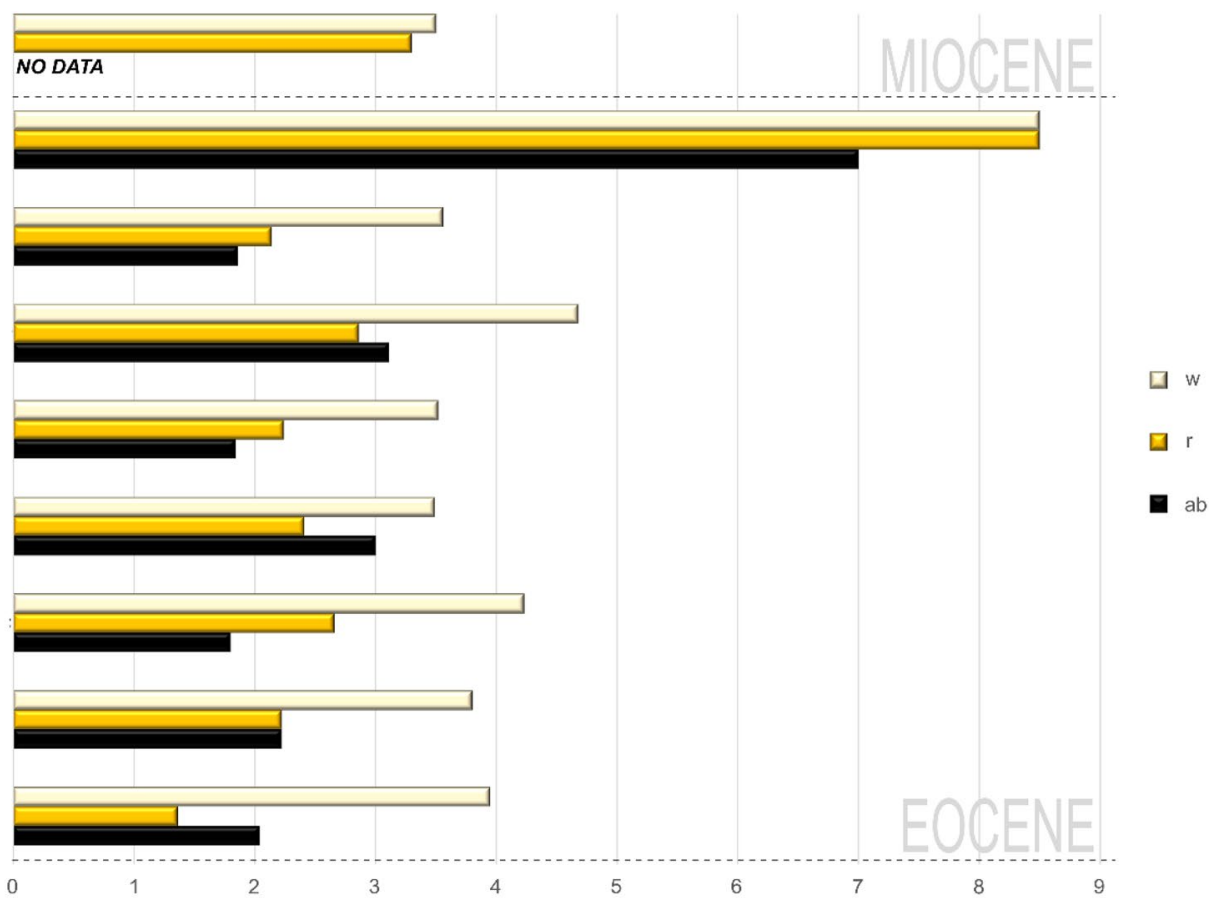

Figure 10. Relation between the length of wing (w), rostrum (r) and abdomen (ab) in different fossil species of Elephantomyia: (A) Elephantomyia (s. str.) grata, (B) Elephantomyia (s. str.) baltica, (C) Elephantomyia (s. str.) bozenae, (D) Elephantomyia (s. str.) brevipalpa, (E) Elephantomyia (s. str.) christelae sp. nov., (F) Elephantomyia (s. str.) irinae, (G) Elephantomyia (s. str.) longirostris, (H) Elephantomyia (s. str.) pulchella, (I) Elephantomyia (Hoffeinsonia) prima subgen. et sp. nov.

E. pulchella ${ }^{7}$ Rostrum elongate, as long or longer than abdomen, only slightly shorter than wing . ...8.

8. Wing approximately $1 / 3$ longer than rostrum (Fig. $10 \mathrm{H}$ ); cross-vein $\mathrm{m}$-cu in $1 / 2$ of $\mathrm{d}$-cell length

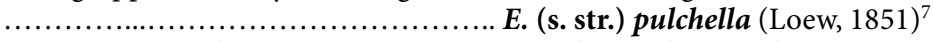

Rostrum very elongate, wing approximately 1/5 longer than rostrum (Fig. 10G); cross-vein m-cu shortly beyond the fork of $\mathrm{Mb}$ on $\mathrm{M} 1+2$ and $\mathrm{M} 3+4$ measured from the base of the wing (Fig. 8E) E. (s. str.) longirostris Loew ${ }^{7}$.

\section{Discussion}

Craneflies from the genus Elephantomyia to present were represented in the fossil record only by the subgenus Elephantomyia. The most well known species from the fossil record were described on the basis of inclusions in Eocene Baltic amber. We do not know the older representatives of the genus Elephantomyia. One species was described from a younger period (the Miocene) ${ }^{9}$ (Fig. 8) and to this day it has not been classified under any subgenus of the genus Elephantomyia. After careful analysis, it was possible to indicate herein that this species, like the other species described based on fossil material, belongs to the nominative subgenus Elephantomyia. So, of the four known subgenera of the genus Elephantomyia, only one is represented in the fossil record. The subgenus Elephantomyia is also the most diverse in modern fauna ${ }^{5}$.

There are over 100 species belonging to the subgenus Elephantomyia occurring in modern fauna. Subgenera like Elephantomyina and Xenoelephantomyia are represented by only single species ${ }^{5}$.

The characteristic morphological features of the newly discovered specimens mentioned in this paper allows the indication and description of a new subgenus of Elephantomyia.

The general features which characterize the genus Elephantomyia are: very elongate rostrum, sometimes longer than the body length, maxillary palpus four segmented, first palpomere reduced, atrophy of cross-vein $r-r\left(R_{2}\right)$ and comparatively short and wide gonocoxites with small gonostyles ${ }^{25,29-31}$. The combination of features such as legs at least partially pale, these parts almost white, vein $R_{1}$ is straight, basal half of vein $R_{2+3+4}$ is sharply arched to the upper edge of wing, veins $R_{2+3+4}$ and $R_{1}$ are positioned closer together than veins $R_{2+3+4}$ and $R_{5}$ and pale brown oval pterostigma, wing without colour pattern distinguish the new subgenus from other subgenera within the genus (Fig. 8).

It is also worth noting that the fossil subgenus Hoffeinsonia subgen. nov. shares features with the extant subgenera Elephantomyodes [such as basal half of vein $\mathrm{R}_{2+3+4}$ sharpy arched to the upper edge of wing, veins $R_{2+3+4}$ and $R_{1}$ running closer together than veins $R_{2+3+4}$ and $R_{5}$ and straight $R_{1}$, reduced palpi, legs with very light (almost white) parts)] and Elephantomyia (such us oval pterostigma and wing distinctly wider than in Elephantomyodes) (Fig. 9). These similarities can indicate a phylogenetic relationship of Hoffeinsonia subgen. nov. and Elephantomyodes or Elephantomyia. The colour patterns of legs are rather rare in craneflies belonging 
to subgenus Elephantomyia and are very variable among taxa, eg. Elephantomyia (s. str.) catarractes Gavryushin $2016^{32}$ described from Tanzania, Morogoro env., Uluguru Mts, Majiyanakwendo waterfall, characterized by the colour pattern of legs which are mostly brown with tips of femora conspicuously yellow ${ }^{32}$. The relation between the length of wing, rostrum and abdomen of Elephantomyia (Hoffeinsonia) prima subgen. nov. is also different than in fossil representatives of Elephantomyia. The rostrum of Elephantomyia (Hoffeinsonia) prima subgen. et sp. nov. measures no more than 1/3 wing length, while in fossil Elephantomyia rostrum measures at least half wing length (Fig. 10).

Fossil records prove the existence of these insects as early as the Eocene. The discovery of the new subgenus sheds new light on the diversity of the genus Elephantomyia, the evolution of the Limoniidae and introduces important information that can be used in further research on the phylogenetic relationships of this group of insects.

The presence in Baltic amber of inclusions of flies of the genus Elephantomyia with a very elongate rostrum adapted to a specific food spectrum (most likely the nectar of Angiospermae flowers) can provide evidence that in "Baltic amber forests" were plants pollinated by these insects. This co-evolution of Angiospermae and Limoniinae began much earlier, in Cretaceous. From Cretaceous period are known species of genus Helius which are characterized by an elongate rostrum - flies adapted to feed on the nectar of Angiospermae flowers. This genus is closely related to Elephantomyia ${ }^{33,34}$.

It has been also proven that the Baltic amber flora comprises elements of both extant northern American and East Asian warm-temperature flora in "Baltic amber forests" and humid climate ${ }^{20}$. Recent species of subgenus Elephantomyia occur mainly in Neotropical and Afrotropical regions ${ }^{3}$ and are represented as an inclusions in Baltic amber while Elephantomyodes occur in Holarctic region. But, its absence in Baltic amber may be due to the fact that these insects were very rare in the Eocene, as in modern fauna ${ }^{5}$.

\section{Material and methods}

The study was based on four inclusions in Eocene Baltic amber from the collection of Christel and Hans Werner Hoffeins. The holotypes of new described species herein are deposited in Senckenberg Deutsches Entomologisches Institut (SDEI) Müncheberg, Germany. The specimens were examined using a Nikon SMZ 1500 stereomicroscope equipped with a Nikon DS-Fil camera. The measurements were taken with NIS-Elements D 3.0 software. The length of head was measured as length of head capsule excluding rostrum. The length of the discal cell-measurements were given from its posterior edge to the point of connection of vein $\mathrm{m}$ - $\mathrm{m}$ with vein $\mathrm{M}_{3}$, the length of the vein $\mathrm{M}_{3}$-measurements were given from the point of connection of vein $\mathrm{m}-\mathrm{m}$ with vein $\mathrm{M}_{3}$ to the margin of wing. The length of hypopygium was measured from the posterior margin of tergite IX to the apex of gonocoxite. The measurements and the relationship between the length of rostrum, wing and abdomen were given only in case when relevant structures were not distorted. Drawings were made by tracing the specimens and the photographs. Drawings and photographs (Figs. 2, 3, 4, 5, and 6, graphics 8-10 partially) were made by Iwona Kania-Kłosok. The map was built using the map Maps-For-Free (https:// maps- for- free. com) and modified with the software programs Corel Draw and Corel Photopaint X7. The stratigraphic chart was used according to International Stratigraphic Chart, International Commission of Stratigraphy (v. 2021/05) https://stratigraphy.org/chart. The wing venation follows that of ${ }^{38}$, terminology applied to the male genitalia nomenclature, is in accordance ${ }^{8,30,39}$.

Received: 19 September 2021; Accepted: 26 November 2021

Published online: 08 December 2021

\section{References}

1. Osten Sacken, C. R. New genera and species of North American Tipulidae with short palpi, with an attempt at a new classification of the tribe. Proc Acad. Nat. Sci. Philadelphia 1859, 197-254 (1860).

2. Alexander, C. P. New or little-known Tipulidae (Diptera) LIV Neotropical species. Ann. Magazine Nat. Hhistory 11(1), 336-362 (1938).

3. Alexander, C. P. New species of craneflies from tropical America (Diptera: Tipulidae) I. J. Kansas Entomol. Soc. 38, 401-407 (1965).

4. Alexander, C. P. Undescribed species of Japanese crane-flies (Tipulidae, Diptera) Part III. Ann. Entomol. Soc. Am. 16, 57-76 (1923).

5. Oosterbroek, P. Catalogue of the Crane-flies of the World. (Diptera, Tipuloidea: Pediciidae, Limoniidae, Cylindrotomidae, Tipulidae). http://nlbif.eti.uva.nl/ccw/index.php. Last updated 08 November 2021 (2021).

6. Alexander, C. P. Crane flies of the Baltic amber (Diptera). Bernstein-Forschungen 2, 1-135 (1931).

7. Loew, H. Beschreibung einiger neuen Tipularia terricola. Linnaea Entomologica 5, 385-418 (1851)

8. Kania, I. Subfamily Limoniinae Speiser 1909 (Diptera, Limoniidae) from Baltic amber (Eocene): the genus Elephantomyia Osten Sacken 1860. PLoS ONE 10(2), 117434 (2015).

9. Podenas, S. \& Poinar, G. O. New crane flies (Diptera: Tipulidae, Limoniidae) from Dominican and Mexican amber. Proc. Entomol. Soc. Wash. 103(4), 863-878 (2001).

10. Sadowski, E.-M., Schmidt, A. R. \& Denk, T. Staminate inflorescences with in situ pollen from Eocene Baltic amber reveal high diversity in Fagaceae (oak family). Willdenowia 50, 405-517 (2020).

11. Linnaeus, C. Systema nature per regna tria naturae, secundum classes, ordines, genera, species, cum caracteribus, differentiis, synonymi, locis. Tomus I. Editio decima, reformata. L. Salvii, Holmiae [= Stockholm] pp. 824 (1758).

12. Rohdendorf, B. B. The oldest infraorders of Diptera from the Triassic of Middle Asia. Palaeontologicheskoi Zhurnal 2, 90-100 (1961).

13. Speiser, P. 4 Orthoptera Orthoptera Nematocera Wissenschaftliche Ergebnisse der Schwedischen Zoologische Expededition nach Kilimandjaro. Meru Diptera 10, 31-65 (1909).

14. Westwood, J. O. Insectorum nonnullorum novorum (ex ordine Dipterorum) descriptiones. Annales de la Societe Entomologique de France 1(4), 681-685 (1835).

15. Osten Sacken, C. R. Monographs of the Diptera of North America Part IV. Smithsonian Miscellaneous Collect. 8(219), 1-345 (1869).

16. Clauer, N., Huggett, J. M. \& Hillier, S. How reliable is the K-Ar glauconite chronometer? A case study of Eocene sediments from the Isle of Wight. Clay Miner 40, 167-176 (2005). 
17. Grimaldi, D. \& Ross, A. J. Extraordinary Lagerstatten in amber, with particular reference to the Cretaceous of Burma. P. 303, in: Fraser, N.C. \& Sues, H.-D. (ed.), Terrestrial conservation Lagerstatten: windows into the evolution of life on land. Edinburgh: Dunedin Academic Press (2017).

18. Kasiński, J. R. \& Kramarska, R. Sedimentary environment of amber-bearing association along the Polish-Russian Baltic coastline. Exkursionsfuhrer und Veroffentlichungen der Deutschen Gesellschaft fur Geowissenschaften 236, 46-57 (2008).

19. Kosmowska-Ceranowicz, B., Kohlman-Adamska, A. \& Grabowska, I. Erste Ergebnisse zur Lithologie und Palynologie der bernsteinfuhrenden Sedimente im Tagebau Primorskoje. Metalla Sonderh 1, 5-17 (1997).

20. Sadowski, E.-M., Seyfullah, L. J., Schmidt, A. R. \& Kunzmann, L. Conifers of the 'Baltic amber forest' and their palaeoecological significance. Stapfia 106, 1-73 (2017).

21. Standke, G. Die Tertiärprofile der Samlandischen Bernsteinkuste bei Rauschen. Schriftenreihe Geowiss 7, 93-133 (1998).

22. Standke, G. Bitterfelder Bernstein gleich Baltischer Bernstein? - Eine geologische Raum- Zeit- Betrachtung und genetische Schlusfolgerungen. Exkursionsfuhrer und Veroffentlichungen der Deutschen Gesellschaft fur Geowissenschaften 236, 11-33 (2008).

23. Kasiński, J. R., Kramarska, R., Sodkowska, B., Sivkov, V. \& Piwocki, M. Paleocene and Eocene deposits on the eastern margin of the Gulf of Gdansk (Yantarny P-1 bore hole, Kaliningrad region, Russia). Geol. Quart. 64(1), 29-53 (2020).

24. Ritzkowski, S. K-Ar - Altersbestimmungen der bernsteinführenden Sedimente des Samlands (Paläogen, Bezirk Kaliningrad). Metalla Sonderheft. Neue Erkenntnisse zum Bernstein 66, 19-23 (1997).

25. Osten Sacken, C. R. Description of some new genera and species of North American Limnobina Part I. Proc. Acad. Sci. Philadelphia 4, 224-242 (1865)

26. Zhang, X., Li, Y. \& Yang, D. A review of the genus Elephantomyia Osten Sacken from China, with descriptions of two new species (Diptera, Limoniidae). Zootaxa 3919(3), 553-572 (2015).

27. Ito, S. Zwei fur die Fauna von Insel Kyushu neue Tipuliden. Mushi 18, 93 (1948).

28. Alexander, C. P. New or little-known Tipulidae from eastern Asia (Diptera) XXXII. Philippine J. Sci. 61, 113-149 (1936).

29. Wood, H. G. The crane-flies of the South-West Cape (Diptera, Tipuloidea). Ann. South Afr. Museum 39, 1-327 (1952).

30. Ribeiro, G. C. \& Amorim, D. S. A review of the genus Elephantomyia Osten Sacken in Brazil, with description of two new species (Diptera: Tipulomorpha, Limoniidae). Zootaxa 46, 1-16 (2002).

31. Alexander, C. P. New or insufficiently-known crane-flies from New Caledonia (Diptera: Tipulidae) Part I. Ann. Entomol. Soc. Am. 41, 137-148 (1948).

32. Gavryushin, D. I. Six new species of limoniid flies (Diptera: Limoniidae) from Tanzania and notes on other species new to the country's fauna. Russian Entomol. J. 25, 273-286 (2016).

33. Krzemiński, W., Kania, I. \& Azar, D. The Early Cretaceous evidence of rapid evolution of the genus Helius Lepeletier \& Serville 1828 (Limoniidae, Diptera). Cretac. Res. 48, 96-101 (2014).

34. Kania, I., Krzemiński, W. \& Azar, D. The oldest representative of Helius Lepeletier \& Serville 1828 (Diptera: Limoniidae) from Lebanese amber (Early Cretaceous). Insect System. Evolut. 44, 231-238 (2013).

35. Lackschewitz, P. Der Formenkreis der Tipula lateralis Meig. (s. lat.) im Ostbaltischen Gebiet. Arbeiten des Naturforscher-Vereins $z u$ Riga (N.F.) 15, 1-16 (1923).

36. Podenas, S., Byun, H.-W. \& Kim, S.-K. Limoniinae crane flies (Diptera: Limoniidae) new to Korea. J. Spec. Res. 4, 61-96 (2015).

37. Alexander, C. P. New or little-known crane-flies from the Amazonian region. Proc. Acad. Sci. Philadelphia 73, 39-103 (1921).

38. Krzemiński, W. Triassic and Lower Jurassic stage of Diptera evolution. Mitteilungen der Schweizerischen Entomologischen Gesellschaft 65, 39-59 (1992).

39. Perrichot, V., Krzemiński, W. \& Nel, A. A new crane fly (Diptera: Limoniidae) from the Cretaceous amber of France. Alavesia 1, $75-80$ (2007).

\section{Acknowledgements}

We would like to thanks to Christel and Hans Werner Hoffeins (Hamburg, Germany) for making the Elephantomyia specimens available for our study. We would especially like to thank Vitalii Alekseev (Kaliningrad) for very valuable comments and corrections of the text, we would like to acknowledge an Anonymous Reviewer for important information and notes. We say thank you to Paul Makin and Joseph Ohimor for proofreading English and Wiktoria Jordan-Stasiło (University of Rzeszów) for making the graphics: map and part of the diagrams. This research was supported by the project of the National Science Centre, Poland, Grant No. 2020/37/B/NZ8/03042.

\section{Author contributions}

I.K.-K. conceived and designed the study, lead and performed the data analysis, interpretations and writing, making photographs, drawings, graphical figures, analysis, writing and corrections of the manuscript. W.K. analysis and corrections of the manuscript. All authors reviewed manuscript.

\section{Funding}

Open Access funding enabled and organized by National Science Centre of Poland, grant number 2020/37/B/ $\mathrm{NZ8/03042.}$

\section{Competing interests}

The authors declare no competing interests.

\section{Additional information}

Correspondence and requests for materials should be addressed to I.K.-K.

Reprints and permissions information is available at www.nature.com/reprints.

Publisher's note Springer Nature remains neutral with regard to jurisdictional claims in published maps and institutional affiliations. 
(c) (i) Open Access This article is licensed under a Creative Commons Attribution 4.0 International cc) License, which permits use, sharing, adaptation, distribution and reproduction in any medium or format, as long as you give appropriate credit to the original author(s) and the source, provide a link to the Creative Commons licence, and indicate if changes were made. The images or other third party material in this article are included in the article's Creative Commons licence, unless indicated otherwise in a credit line to the material. If material is not included in the article's Creative Commons licence and your intended use is not permitted by statutory regulation or exceeds the permitted use, you will need to obtain permission directly from the copyright holder. To view a copy of this licence, visit http://creativecommons.org/licenses/by/4.0/.

(C) The Author(s) 2021, corrected publication 2021 